Opini

\title{
STANDARISASI KURSUS: ANTARA KEBUTUHAN DAN KESULITAN MENETAPKAN BENCHMARK
}

\begin{abstract}
Supriyono*
Abstract

Course institutions are one kind of well-known non-formal education unit in Indonesia. Its role and contribution in the development of national system and the development of human resources can not be neglected. The amount of course institutions fluctuates overtime; however, it can be assured that the amount stays significantly fulfilling the learning need of the people. In 2002, the recorded amount of course institution is 22,510, but it decreased up to 11,745 in 2005. Those institutions provide 167 types of courses and trainings, which can be categorized into several subjects of study. According to the Government Regulation of Number 19 in 2005 on the National Standard of Education, course institutions need to have standardization. Different from the formal education (school) standard which is more systematical and homogeneous, the standardization for course institutions faces obstacles related to the minimum criteria of several components because of the wide variability and heterogeneity on its types, scopes, and levels.
\end{abstract}

Key words: course institution, standardization, non-formal education.

\section{PENDAHULUAN}

Salah satu program pendidikan pada jalur pendidikan nonformal adalah kursus dan pelatihan yang berfungsi sebagai penambah dan pelengkap bagi pendidikan formal, di samping berfungsi integrative sebagai pendidikan lanjutan bagi warga negara yang membutuhkan peningkatan kemampuan dalam menghadapi dan menyesuaikan diri dengan lingkungan, khususnya dunia kerja yang terus berkembang. Kursus merupakan satuan pendidikan nonformal bagi masyarakat dengan tidak membatasi usia.

Dalam Undang-Undang Nomor 20 Tahun 2003 tentang Sistem Pendidikan Nasional ada beberapa ayat yang mengatur tentang kursus, khususnya pada pasal 26 ayat [4] dan ayat [5]. Kursus dan pelatihan diselenggarakan bagi masyarakat yang memerlukan bekal pengetahuan, keterampilan, kecakapan hidup, dan sikap untuk mengembangkan diri, mengembangkan profesi, bekerja, usaha mandiri, dan/atau melanjutkan pendidikan yang lebih tinggi. Penyebutan istilah (frase) "kursus" selalu digandeng dengan kata "pelatihan" (pasal 26 ayat [5]), meskipun pada ayat [4] secara eksplisit disebutkan lembaga kursus adalah terpisah atau berbeda dengan lembaga pelatihan. Dalam tulisan ini yang dimaksud kursus adalah kegiatan pembelajaran dan pendidikan yang diselenggarakan oleh warga masyarakat bagi warga masyarakat yang memerlukan

* Dosen PLS Universitas Negeri Malang bekal pengetahuan, keterampilan, kecakapan hidup, dan sikap untuk mengembangkan diri, mengembangkan profesi, bekerja, usaha mandiri, menyiapkan diri untuk melanjutkan pendidikan yang lebih tinggi, dan/atau melaksanakan program pendidikan berkelanjutan. Penyelenggaraan kursus dan pelatihan lebih berorientasi pada kebutuhan masyarakat dan kebutuhan pasar kerja. Dalam istilah lain kehadiran lembaga kursus senanatiasa dikaitkan dan terkait dengan dorongan kebutuhan (belajar) masyarakat (demand driven).

Orientasi pada program pembelajaran yang berorientasi pada kompetensi fungsional, kebutuhan belajar sesaat dan keinginan untuk segera menerapkan dan memetik hasil belajar merupakan karakter dasar program kursus. Oleh karena itu program pendidikan pada lembaga kursus biasanya bersifat temporal, luwes, fungsional, berkonten dan berdesain lokal, serta bersifat fragmentaristis. Program kursus sangat mudah berkembang menanjak, cepat pula pudar dan menghilang. Apabila sebuah kebutuhan ketrampilan teknis tertentu tengah menjadi kebutuhan pasar kerja, maka dengan serta merta lembaga kursus akan menyiapkan program pembelajarannya, dan bertumbuhanlah lembaga dan program kursus untuk jenis keterampilan tersebut. Selanjutnya, bila pasar kerja untuk jenis ketrampilan tersebut telah jenuh atau menghilang maka serta merta menghilang pula program kursus untuk jenis kompetensi yang bersangkutan. 
Contoh paling nyata adalah sudah tidak adanya lagi kursus mengetik manual, karena ketrampilan mengetik manual sudah tidak ada di pasaran kerja. Padahal pada tahun 1970-1980-an banyak terdapat kursus mengetik.

Jenis dan variabilitas program kursus sangatlah heterogen. Ada program kursus yang sangat singkat waktunya dan sederhana struktur kurikulumnya, ada juga kursus yang sangat panjang waktunya dan rumit struktur kurikulumnya. Contoh program kursus yang sederhana itu misalnya kursus menghias parsel lebaran yang dapat selesai dalam dua tiga jam pelajaran. Contoh program kursus yang rumit, misalnya kursus tata rias pengantin, kursus bahasa Inggris, kursus komputer, dan sebagainya yang tidak hanya berjenjangjenjang, namun juga berjenis-jenis paket program yang ditawarkan lembaga kursus. Dari aspek penyelenggaraanya, rentang variasinya juga cukup besar. Ada lembaga kursus yang diselenggarakan di bekas garasi mobil atau ruang sederhana, ada juga yang diselenggarakan di gedung megah berfasilitas mewah. Ada lembaga kursus yang dimiliki dan dikelola perorangan (saja) ada juga yang dikelola oleh sebuah corporate yang berstruktur manajemen besar.

\section{PEMBAHASAN}

\section{Kebutuhan Standarisasi}

Kursus pada mulanya dikembangkan untuk mengembangkan keterampilan praktis bagi warga masyarakat yang membutuhkannya, dan hasilnya langsung digunakan untuk mencari nafkah. Namun, sejalan dengan perkembangan ilmu pengetahuan dan teknologi, kursus yang pada mulanya berorientasi pada penyajian keterampilan kepada peserta didik, kemudian berkembang bukan saja berorientasi pada keterampilan (vocational skills) melainkan juga pegetahuan, keterampilan, dan sikap. Adanya perkembangan orientasi tersebut, pada akhirnya kursus sebagai salah satu satuan pendidikan nonformal diselenggarakan bagi warga masyarakat yang memerlukan bekal untuk mengembangkan diri, bekerja mencari nafkah, dan/atau melanjutkan ke jenjang pendidikan yang lebih tinggi. Demikian pula program kursus diselenggarakan secara berjenjang dan berkesinambungan. Penjejangan itu ada yang menyebutkan sebagai tingkatan dasar, terampil, dan mahir. Ada yang menyebutnya dengan istilah tingkatan muda, madya, dan pratama. Ada lagi yang menyebutnya dengan istilah tingkat elementary, intermediate, dan advance. Walaupun ada sebagian program kursus yang tidak berjenjang sama sekali dan juga tidak berkesinambungan, misalnya kursus merawat jenazah, kursus menghias parsel, kursus menggunakan kompor gas, dan sebagainya. Kursus itu hanya dijalani dalam "satu kali gebrakan dan selesai".

Berdasarkan subject matter (muatan materi/ kompetensi) dan pemanfaatan hasil belajar, klasifikasi kursus dapat dibedakan menjadi tiga kelompok. Pertama, adalah kursus yang berfungsi meningkatkan kemampuan belajar melalui pelajaran tambahan untuk bidang-bidang tertentu. Kursus semacam ini disebut dengan bimbingan belajar, seperti IPA, Matematika, Bahasa Inggris, dan lain-lain dengan sasaran siswa SDSMTA, serta sasaran pelajar pada tingkat tertentu, misalnya kelas III SMTA yang akan mengikuti tes UMPTN. Kedua, adalah kursus yang berfungsi memberikan atau meningkatkan keterampilan. Kursus semacam ini disebut dengan pendidikan keterampilan vokasional, seperti mengetik, kecantikan, bahasa asing, akuntansi, montir, menjahit, sablon, babysitter, dan lainlain. Sasaran lembaga ini, mayoritas, adalah para lulusan SD, SMP dan SMTA yang memerlukan sertifikat keterampilan untuk mencari pekerjaan pada tingkat vokasi. Ketiga, adalah kursus untuk pengembangan profesi, seperti kursus sekretaris atau humas di perusahaan, akuntan publik, kepribadian, dan lain-lain. Sasarannya adalah Iulusan SMTA sampai berpendidikan tinggi, dari yang belum bekerja sampai dengan yang sudah bekerja, namun ingin meningkatkan kemampuan profesionalismenya. Jenis ketiga ini lebih mengarah pada pembentukan pencitraan (image) dalam masyarakat, dan bukan sekadar memberikan keterampilan teknis. Oleh karena itu dari segi waktu pelaksanaannya, kursus jenis ketiga itu waktunya lebih panjang, yakni antara enam bulan sampai dua tahun.

Apabila dikaitkan dengan tingkatan keterampilan dan keahlian manusia dalam mencari nafkah, kursus mempersiapkan orang untuk mendapatkan kemampuan vokasional. Tingkatan paling rendah cara orang mencari nafkah disebut okupasi (occupation). Di kurusus itu mendapatkan nafkah dengan bekerja apa saja secara tradisional tanpa mempersyaratkan ketrampilan kerja yang rumit, misalnya pencari rumput, pancari pasir tradisoinal, pemecah batu koral, atau pekerjaanpekerjaan kasar lainnya seperti kuli bangunan dan kuli angkut. Tingkatan menengah adalah pekerja vokasional, di mana membutuhkan ketrampilan tangan tingkat menengah yang didapat melalui latihan-latihan sistematis. Termasuk jenis pekerjaan ini misalnya tukang kayu, tukang batu, penjahit, teknisi listrik, teknisi komputer, dan sebagainya. Tingkatan tertinggi 
adalah tenaga profesional, yang membutuhkan pendidikan keahlian tingkat tinggi yang hanya bisa didapat di perguruan tinggi akademik. Termasuk jenis pekerjaan ini adalah dokter, insinyur, akuntan, ahli hukum, guru, dan sebagainya.

Kursus merupakan suatu bentuk layanan pendidikan luar sekolah yang diselenggarakan dan dilaksanakan di tengah-tengah masyarakat. Menurut Zainuddin Arif, kursus adalah suatu format belajar yang tradisonal dalam lembaga pendidikan yang berupa suatu kelompok peserta, yang pertemuannya dilakukan dalam waktu tertentu dengan lama waktu tertentu pula dalam rangka untuk mempelajari suatu bidang studi yang terbatas dibawah bimbingan seorang instruktur/ guru (Arif:1986:51). Dengan demikian kursus ini dibangun dan diselenggarakan sejajar dengan kebutuhan yang dirasakan oleh masyarakat baik untuk menambah keterampilan, usaha sosial ekonomi, pengisi waktu luang ataupun upaya pengembangan diri seseorang. Kursus merupakan pendidikan yang efektif dalam membina pengetahuan serta meningkatkan kesiapan dalam memasuki lapangan pekerjaan yang dapat memberikan "income generating" maupun employment generating." Lebih lanjut Arif (1986:51) mengemukakan bahwa kursus masih merupakan salah satu kegiatan belajar yang paling efisien dan paling dapat diterima serta merupakan alat yang dinamis dan fleksibel dalam membantu belajar. Realita ini muncul sebagai jawaban atas fenomena tentang kesenjangan atas hasil pendidikan persekolahan dengan tuntutan masyarakat yang semakin meningkat

Ada beberapa alasan yang mendasari pentingnya lembaga kursus sebagai bagian dari pendidikan nasional dalam mendidik masyarakat. Pertama, meningkatnya jumlah penduduk usia sekolah yang diikuti oleh meningkatnya aspirasi pendidikan masyarakat tidak terserap secara penuh dan kurang terlayani seluruhnya oleh sistem pendidikan sekolah. Keadaan ini cendrung membuat mahalnya biaya pendidikan formal untuk meningkatkan kualitasnya. Dampak lainnya adalah banyaknya siswa yang dropout dan rendahnya mutu pendidikan serta rendahnya kualitas angkatan kerjanya. Selain itu, kenyataan menunjukan bahwa semakin tahun semakin banyak penduduk usia sekolah setelah lulus dari SD, SLTP, SLTA tidak dapat melanjutkan pendidikan di dalam sistem pendidikan sekolah. Apabila kita sudah sepakat bahwa pendidikan itu berlangsung seumur hidup, dan setiap individu itu merupakan learning station maka satu-satunya sistem pendidikan dapat mengurangi jurang perbedaan antara penduduk yang berpendidikan dan yang tidak atau kurang berpendidikan adalah pendidikan luar sekolah (Soegiyanto:1989).

Kedua, lembaga kursus sebagai bagian dari pendidikan luar sekolah dapat melakukan fungsinya sebagai pelengkap atas kekurangan yang terdapat pada sistem pendidikan sekolah. Sebagaimana kita ketahui bahwa pendidikan formal persekolahan hanya menekankan pada kemampuan mengetahui dan menguasai keterampilan-keterampilan tertentu, yang kurang menekankan pada bidang-bidang afektif peserta didik, atau kurang berorientasi pada nilai-nilai tertentu yang diperlukan warga belajar untuk memasuki dunia kerja. Selain itu pendidikan sekolah saat ini cenderung memberikan posisiposisi kekuasaan dan kekayaan bagi mereka yang telah menyelesaikan jenjang-jenjang pendidikan formal. Karena berbagai keterbatasan pendidikan sekolah, tidak mampu menciptakan kesempatan bagi semua yang ingin melanjutkan pendidikan sehingga yang tertinggal tidak atau sulit untuk melakukan upward mobility. Dengan sistem pendidikan luar sekolah yang lebih mementingkan kompetensi daripada kridendsialnya (ijasah, sertifikat, gelar) diharapkan dapat digunakan sebagai alasan untuk perbaikan sistem penerimaan tenaga kerja untuk penempatannya pada prinsip-prinsip tertentu.

Ketiga, lembaga kursus mampu merealisasikan keuntungan dari pendidikan sekolah. Biaya untuk meningkatkan kualitas SDM melalui pendidikan sekolah sangat mahal. Akan tetapi, jumlah anak yang tidak dapat melanjutkan pendidikan yang lebih tinggi sangat besar. Investasi akan sangat kurang bermanfaat bila tidak diciptakan kesempatan belajar yang lain bagi yang meninggalkan jalur pendidikan sekolah. Dengan demikian, menciptakan kesempatan belajar untuk life long learning melalui jalur pendidikan luar sekolah merupakan suatu kebutuhan. Sebab, kebutuhan akan pengetahuan dan keterampilan dalam 
era-globalisasi dewasa ini sudah menjadi kebutuhan dasar. Pengetahuan dan keterampilan yang dimiliki seseorang menunjukan kualitasnya. Makin tinggi tingkat pengetahuan dan keterampilannya, makin menunjukan kemampuan berfikir kritis. Dalam kaitan hal tersebut Rogers dan Shomaker (1997:13) mengemukakan bahwa semakin tinggi tingkat pendidikan seseorang maka semakin luas pengetahuannya dan semakin menerima hal-hal baru. Selanjutnya muncul pula kebutuhan belajar akan halhal yang lebih baru lagi. Kursus merupakan salah satu alternatif bagi masyarakat untuk memenuhi kebutuhan pembelajaran. Combs (1974) menganggap bahwa pendidikan nonformal yang tepat, seperti kursus dapat dijadikan sebagai suatu alternatif selain pendidikan formal untuk pengembangan dan perubahan.

Lembaga kursus dan masyarakat membentuk suatu simbisosis mutualisma yang saling memberi manfaat, sehingga keberadaannya merupakan milik masyarakat. Hasil-hasil pelatihan keterampilan pada lembaga kursus akan memberikan dampak yang positif terhadap kemajuan pola pikir individu sehingga muncul kemandirian dan kepekaan dalam memanfaatkan momentum yang memberi harapan lapangan kerja. Oleh karena itu, lembaga kursus bisa disebut sebagai lembaga pendidikan penyiapan kerja bagi pencari kerja (job seeker). Adapun pelatihan (training) adalah lembaga pendidikan yang berfungsi meningkatkan keterampilan, pengetahuan, dan sikap kerja para karyawan dan juga para pekerja mandiri sehingga melalui pelatihan tersebut produktivitas kerja karyawan/ pekerja dapat ditingkatkan yang pada akhirnya dapat meningkatkan produktivitas perusahaan atau organisasi.

Eksistensi lembaga kurus ditengah masyarakat bertujuan untuk: (1) memperluas jangkauan pendidikan kepada masayarakt yang tidak dapat dididik oleh lembaga sekolah formal, (2) mempercepat proses penguasaan ilmu pengetahuan dan ketarampilan praktis bagi masyarakat, dan (3) pemerataan temuan ilmu pengetahuan serta keterampilan kepada masyarakat. Sedangkan fungsi lembaga kursus (Soedomo, 1989:45, Sudjana, 2000) yaitu: (1) sebagai pengganti (replacement) pendidikan sekolah, (2) pelengkap (complement) pendidikan sekolah, (3) sebagai penunjang (suplement) pendidikan sekolah.

Penyelenggaraan kursus dapat dilakukan oleh berbagai pihak. Undang-Undang Nomor 20 tahun 2003 mengklasifikasi penyelenggara kursus mejadi tiga macam, yaitu: pemerintah, swasta, dan perwakilan asing atau lembaga internasional. Keragaman penyelenggaraan kursus itu berdampak pada variasi jenis, ruang lingkup, tingkatan, dan layanan yang diberikan kepada peserta didik. Dalam upaya menciptakan kelembagaan, proses, dan hasil pendidikan nasional yang bermutu dan dapat dipertanggungjawabkan, termasuk pada program kursus dibutuhkan adanya sebuah standarisasi.

Di antara berbagai jenis dan variasi program dan kelembagaan kursus itu memang diamanatkan adanya standarisasi sebagaimana ketentuan peraturan perundangan Peraturan Pemerintah Nomor 19 Tahun 2005, tentang Standar Nasional Pendidikan, khsusnya pada pasal 86 ayat (1) yang menyatakan bahwa, Pemerintah melakukan akreditasi pada setiap jenjang dan satuan pendidikan untuk menentukan kelayakan program dan/atau satuan pendidikan. Di samping karena tuntutan peraturan perundangan, standarisasi kursus juga dibutuhkan dalam upaya mengembangkan program pendidikan yang bermutu dan bertanggung jawab.

Standarisasi kursus merupakan kriteria minimal yang harus dipenuhi oleh lembaga kursus dalam menyelenggarakan kursus. Peraturan Pemerintah (PP) Nomor 19 Tahun 2005, tentang Standar Nasional Pendidikan, pasal 1 ayat (1) menyatakan bahwa standar nasional pendidikan adalah kriteria minimal tentang sistem pendidikan di seluruh wilayah hukum Negara Kesatuan Republik Indonesia. Standar nasional pendidikan berfungsi sebagai dasar dalam perencanaan, pelaksanaan, dan pengawasan pendidikan dalam rangka mewujudkan pendidikan nasional yang bermutu. Tujuan yang hendak dicapai dalam standar nasional pendidikan yaitu terjaminnya mutu pendidikan nasional dalam rangka mencerdaskan kehidupan bangsa dan membentuk watak serta peradaban bangsa yang bermartabat. Merujuk pada undang-undang tersebut standar kursus dimaksudkan sebagai perangkat untuk mendorong terwujudnya transparansi dan akuntabilitas publik dalam penyelenggaraan kursus. Standar kursus memuat kriteria minimal tentang komponen pendidikan yang memungkinkan rumpun dan jenis kursus mengembangkan pendidikan secara optimal sesuai dengan karakteristik dan kekhasan programnya. Walaupun demikian dalam standar nasional pada jalur pendidikan nonformal tidak serinci dengan pendidikan jalur formal. Hal ini dimungkinkan karena pendidikan nonformal yang memiliki karakteristik tidak terstruktur untuk mengembangkan programnya sesuai dengan kebutuhan masyarakat (Penjelasan PP 19/2005).

Pada tahun 1995/1996 Pemerintah telah melakukan standardisasi penyelenggaraan kursus sebagai tindak lanjut pengembangan program dari kebijakan Menteri Pendidikan dan Kebudayaan tentang link and match antara pendidikan dengan dunia usaha/ 
industri. Kebijakan ini dimaksudkan utuk menyiapkan dan melaksanakan proses pembelajaran yang menghasilkan lulusan yang memiliki kompetensi sesuai dengan kebutuhan dunia usaha/industri dan kebutuhan pembangunan di berbagai bidang. Kebijakan itu diwujudkan melalui penerapan konsep pendidikan dual system (pendidikan sistem ganda) yaitu sistem pendidikan yang dirancang, dilaksanakan, dan dievaluasi bersama oleh lembaga pendidikan dan perusahaan/industri.

Panduan standardisasi kursus pada periode tersebut disusun bersama oleh Direktorat Pendidikan Masyarakat bersama para penyelenggara kursus, perusahaan/industri/ praktisi, tenaga ahli dari subkonsursium dan asosiasi profesi, serta seorang konsultan yang ditempatkan oleh pemerintah Republik Federal Jerman (Depdiknas, 2005:xxii). Panduan itu disusun untuk program kursus satu tahun atau apabila dengan menggunakan sistem semester dilaksanakan untuk dua semester. Proses pengembangan standardisasi kursus kemudian diperkuat dengan Keputusan Menteri Pendidikan dan Kebudayaan Nomor 261/U/1999 tentang Penyelenggaraan Kursus. Pasal 11 ayat 1 menyatakan bahwa standardisasi kursus diselenggarakan untuk menjamin mutu penyelenggaraan kursus yang meliputi warga belajar, kurikulum, tenaga pendidik, sarana dan prasarana, proses belajar mengajar, pengujian, dan sertifikasi.

Dengan berpedoman pada Keputusan Mendikbud tersebut, pada tahun 2003 dari sejumlah lembaga kursus yang ada, sebanyak 200 lembaga kursus yang telah mengikuti standardisasi nasional kursus. Memperhatikan data tersebut tampak bahwa bila ditimbang antara yang siap dengan yang belum siap, yang terakhirlah yang lebih banyak. Jenis kursus yang sudah siap mengikuti standar nasional maupun standar internasional antara lain adalah kursus akuntansi, tata boga, kecantikan, bahasa Inggris, otomotif, dan elektronika. Sementara itu Jalal (2004) menyatakan ada 5-10 persen sudah melewati standarisasi nasional, antara 70 - 80 persen masih diharapkan mencapai standar nasional, dan antara 1015 persen masih jauh dari standar yang dibutuhkan. Pengklasifikasian lembaga kursus itu didasarkan pada pemilikan tiga komponen utama, yaitu: ketersediaan sarana, kemampuan instruktur, dan penggunaan kurikulum. Kelengkapan sarana dianggap sudah mencapai atau paling tidak mendekati standar nasional apabila fasilitas yang dimiliki oleh sebuah lembaga kursus cukup memadai. Termasuk dalam hal ini adalah pelaksanaan proses belajar mengajar yang baik. Kemudian untuk instruktur, menyangkut latar belakang pendidikan, pengalaman, dan profesionalitas.
Besarnya jumlah kursus yang diselenggarakan oleh masyarakat dibandingkan dengan yang diselenggarakan oleh Pemerintah cenderung berakibat pada tidak adanya keseragaman dalam menyediakan standar layanan pendidikan. Artinya, ada lembaga kursus yang mampu menyediakan layanan pendidikan dengan standar pelayanan tinggi, dan sebaliknya ada pula yang memberikan layanan pendidikan dengan standar rendah, kalau tidak boleh dikatakan hanya sekedar menyediakan sarana pendidikan utama yang tidak sebanding dengan jumlah peserta didik yang mengikuti kursus. Walaupun terdapat variasi dalam menyediakan layanan pendidikan, namun berbagai kursus dan pelatihan yang disediakan oleh suatu lembaga kursus dan pelatihan tetap diminati oleh masyarakat, dan lulusan dari berbagai kursus dan pelatihan yang memiliki standar layanan berbeda itu memiliki peluang yang sama dalam memenuhi peluang kerja.

Untuk mengukur keberhasilan warga belajar dalam mengikuti kursus dilakukan melalui ujian lokal, ujian nasional, uji kompetensi, dan ujian internasional. Ujian lokal dilaksanakan oleh lembaga penyelenggara kursus, ujian nasional dilakukan oleh direktorat bagi yang belum terakreditasi, dan ujian kompetensi dilaksanakan oleh lembaga profesi. Ujian internasional dilaksanakan oleh lembaga internasional yang kompeten. Kesemuanya terbuka bagi peserta kursus. Untuk keperluan sertifikasi dibentuk Badan Nasional Sertifikasi Profesi (BNSP) melalui Lembaga Sertifikasi Profesi (LSP). Badan yang berbentuk itu tidak hanya menguji kompetensi tenaga kerja dalam negeri saja, melainkan juga bagi tenaga kerja asing yang ingin bekerja di Indonesia.

Pembentukan BNSP itu sebagaimana telah diamanatkan dalam Undang-undang Nomor 13 Tahun 2003 tentang Ketenagakerjaan, yang bertanggung jawab melaksanakan sertifikasi kompetensi kerja bagi tenaga kerja, baik yang berasal dari lulusan pelatihan kerja dan/atau tenaga kerja yang telah berpengalaman. Karena itu Badan tersebut sangat diperlukan sebagai lembaga yang mempunyai otoritas dan menjadi rujukan dalam penyelenggaraan sertifikasi kompetensi kerja secara nasional. Melalui undang-undang tersebut akan terbangun sistem sertifikasi kompetensi kerja nasional yang diakui oleh semua pihak.

\section{Standarisasi BSNP}

Lahirnya Undang-Undang Nomor 20 Tahun 2003 tentang Sistem Pendidikan Nasional, dan Peraturan Pemerintah Nomor 19 Tahun 2005 tentang Standar Nasional Pendidikan, berimplikasi pada peninjauan kembali panduan yang digunakan dalam men- 
standarkan kursus. Apabila pada mulanya indikator standar nasional kursus hanya didasarkan pada pemenuhan tiga komponen pokok, maka setelah lahirnya undang-undang dan peraturan pemerintah tersebut, indikator yang menjadi tolok ukur standar nasional kursus harus mencakup delapan komponen utama, yaitu: isi, proses, kompetensi lulusan, pendidik dan tenaga kependidikan, sarana dan prasarana, pembiayaan, pengelolaan, dan penilaian. Demikian pula dalam mengukur standar nasional kursus pada mulanya dilakukan bersama-sama Direktorat Pendidikan Masyarakat dengan Asosiasi Kursus dan Konsursium Kursus sejenis, namun dengan lahirnya undang-undang dan peraturan pemerintah tersebut lembaga yang memiliki hak dan kewajiban mengukur standar nasional kursus adalah Badan Standar Nasional Pendidikan, yang dalam operasionalnya dijalankan oleh Badan Akreditasi Nasional Pendidikan Nonformal (BAN PNF).

Pada tahun 2007 Badan Standar Nasional Pendidikan (BSNP) berprakarsa memenuhi tugasnya menyusun standar kursus dan pelatihan dengan membentuk gugus satuan tugas atau tim ahli dengan Surat Keputusan Ketua Badan Standar

Secara umum,
standarisasi kursus ditujukan
untuk menyediakan acuan
nasional bagi semua pihak
yang berkepentingan dalam
pengelolaan dan
peningkatan mutu layanan
kursus dan pelatihan di
wilayah Indonesia.

kursus dan pelatihan; dan (6) menyediakan acuan bagi berbagai pihak yang menangani lembaga kursus dan pelatihan dalam peningkatan mutu pengelolaannya.

Standarisasi kursus secara objektif akan bermanfaat bagi bangsa dan masyarakat dalam halhal: (1) sebagai acuan bagi pengambil kebijakan dalam menetapkan peraturan dan ketentuan penyelenggaraan kursus dan pelatihan; (2) sebagai pedoman bagi pengelola dan pelaksana kursus dan pelatihan dalam melaksanakan kegiatan program kursus dan pelatihan, serta menjaga kehormatan penyelenggara dan kelembagaan kursus dan pelatihan; (3) sebagai acuan pengelola dan pelaksana dalam pengawasan internal dan pengembangan kursus dan pelatihan; (4) sebagai pedoman bagi dinas kabupaten/kota dalam mensupervisi kegiatan program kursus dan pelatihan; dan (5) memberikan perlindungan kepada masyarakat dalam menghindari praktek-praktek penyelenggaraan kursus dan pelatihan yang tidak bermutu dan/atau tidak bertanggung jawab. Oleh karena itu diperlukan standardisasi layanan pendidikan yang diberikan oleh lembaga kursus agar setiap lembaga kursus yang menyelenggarakan jenis kursus yang Nasional Pendidikan (BSNP), Nomor 0588/BSNP/II/ 2007 tanggal 26 Februari 2007 tentang Tim Ahli Standar Kursus dan Pelatihan. Tim ini telah bekerja dan berhasil merumuskan buram naskah Standar Kelembagaan Kursus dan Pelatihan.

Secara umum, standarisasi kursus ditujukan untuk menyediakan acuan nasional bagi semua pihak yang berkepentingan dalam pengelolaan dan peningkatan mutu layanan kursus dan pelatihan di wilayah Indonesia. Secara lebih khusus standarisasi kursus ditujukan untuk: (1) menyediakan acuan bagi penyelenggara dan pengelola lembaga kursus dan pelatihan dalam mengembangkan program pendidikan pada kursus dan pelatihan, (2) memberi pedoman kepada pendidik dan tenaga kependidikan kursus dan pelatihan dalam menyelenggarakan program pembelajaran, (3) menyediakan acuan bagi pengambil kebijakan di bidang PNF dalam menetapkan berbagai kebijakan yang menyangkut kursus dan pelatihan, (4) memberi pedoman bagi penyelenggara dan pengelola lembaga kursus dan pelatihan dalam merencanakan, melaksanakan, dan mengevaluasi program kursus dan pelatihan, (5) memberi pedoman bagi penilik dalam melakukan penilikannya terhadap berbagai program sama di wilayah Indonesia memiliki standar layanan pendidikan yang sama.

Pada awalnya, ditemui berbagai masalah dan problematika ketika hendak merumuskan berbagai pointer standar kursus dan pelatihan. Masalah dan problematika itu terutama terkait dengan ketentuan pasal 1 ayat (1) PP Nomor 19 Tahun 2005 yang menyatakan bahwa standar nasional pendidikan adalah kriteria minimal tentang sistem pendidikan di seluruh wilayah hukum Negara Kesatuan Republik Indonesia. Untuk kursus dan pelatihan, penetapan kriteria minimal tersebut sulit untuk bisa ditetapkan karena tidak mungkin bisa ditemukan "sebuah garis batas" yang mampu menjangkau semua jenis dan tingkatan kursus yang ada di Indonesia, meskipun untuk jenis kursus yang sama. Misalnya, pada kursus Bahasa Inggris, variabilitas tingkatan, sub jenis kursus, dan cakupan kompetensi yang diajarkan sangatlah beragam. Apalagi bila benchmark akan diterapkan terhadap jenis kursus yang berbeda, misalnya standar isi untuk kursus Bahasa Inggris sangat berbeda dengan standar isi untuk kursus akupuntur.

Kesulitan penetapan batas minimal (bench mark) tidak hanya yang terkait dengan standar isi, namun juga menyangkut pada tujuh komponen standar lainnya, 
yaitu standar proses, standar kompetensi lulusan, standar pendidik dan tenaga kependidikan, standar sarana dan prasarana, standar pengelolaan, standar pembiayaan, dan standar penilaian pendidikan. Hanya sebagian kecil dari komponen standar pendidikan tersebut yang bisa diakomodasi dalam standar kursus dan pelatihan apabila perihal yang hendak distandarisasi adalah kursus dan pelatihan sebagai sebuah satuan dan program pendidikan generik. Oleh karena itu pada tahapan awal, tim ad hoc standar kursus dan pelatihan mengambil posisi mengusulkan stadarisasi kursus dan pelatihan pada aspek kelembagaan, sehingga draf naskah yang dihasilkan disebut sebagai Standar Lembaga Kursus dan Pelatihan.

Buram naskah Standar Lembaga Kursus dan Pelatihan diarahkan menuju kriteria minimal dalam rumusan yang bersifat umum yang mencakup komponen kelembagaan yang harus dipenuhi oleh lembaga kursus dan pelatihan yang bersifat substansial. Lingkup Standar Kursus dan Pelatihan substantif itu meliputi: (1) standar isi, (2) standar proses, (3) standar kompetensi lulusan, (4) standar pendidik dan tenaga kependidikan; (5) standar sarana dan prasarana, (6) standar pengelolaan, (7) standar pembiayaan, dan (8) standar penilaian. Keseluruhannya dinyatakan dalam formulasi yang bersifat umum, berlaku untuk setiap jenis kursus dan pelatihan yang sangat beragam, tumbuh dan berkembang di masyarakat Indonesia. Jabaran operasional setiap komponen menjadi ukuran-ukuran kualitatif maupun kuantitatif (akan) dilakukan oleh BAN PNF (Badan Akreditasi Nasional Pendidikan Nonformal). Hal ini dimaksudkan agar modifikasi, penyesuaian, dan perubahan ukuran kualitatif dan kuantitatif dapat dilakukan secara leluasa pada tataran teknis operasional, bukan pada tataran substansial dari komponen sistem kelembagaan kursus dan pelatihan tersebut.

Standar isi adalah ruang lingkup materi dan tingkat kompetensi yang dituangkan dalam kriteria tentang kompetensi tamatan, kompetensi bahan kajian, kompetensi mata pelajaran, dan silabus pembelajaran yang harus dipenuhi oleh peserta didik pada jenjang dan jenis pendidikan tertentu. Standar isi mengatur dan memberikan acuan tentang kerangka dasar dan struktur kurikulum, beban belajar, dan kalender pendidikan pada lembaga kursus.

Standar proses mengatur dan memberikan acuan tentang perencanan, pelaksanaan, penilaian, dan pengawasan pembelajaran. Standar proses berkaitan dengan pelaksanaan pembelajaran pada satu satuan pendidikan untuk mencapai standar kompetensi lulusan. Standar proses pada kursus dan pelatihan mencakup perencanaan pembelajaran, pelaksanaan pembelajaran, penilaian pembelajaran, dan pengawasan.

Standar kompetensi lulusan adalah kualifikasi kemampuan lulusan yang mencakup standar isi, cakupan, dan kegunaan penetapan kompetensi lulusan. Standar kompetensi lulusan mengatur dan memberikan acuan tentang isi, cakupan, dan kegunaan kompetensi lulusan pada lembaga kursus.

Standar pendidik dan tenaga kependidikan adalah kriteria pendidikan prajabatan dan kelayakan fisik maupun mental, serta pendidikan dalam jabatan. Standar pendidik dan tenaga kependidikan pada kursus dan pelatihan meliputi jenis ketenagaan yang perlu ada, rekrutasi dan penempatan, serta kualifikasi masingmasing jenis ketenagaan. Dalam standar lembaga kursus dan pelatihan diatur tentang jenis ketenagaan, cara merekrut dan menugaskan, serta kualifikasi akademik dan kompetensi.

Standar sarana dan prasarana adalah standar nasional pendidikan yang berkaitan dengan kriteria minimal tentang ruang-ruang dan tempat-tempat yang diperlukan untuk menunjang proses pembelajaran, termasuk penggunaan teknologi informasi dan komunikasi. Standar sarana dan prasarana mengatur dan memberikan acuan tentang jenis, perencanaan, dan pengelolaaan sarana dan prasarana lembaga kursus.

Standar pengelolaan pendidikan untuk kursus dan pelatihan adalah kelengkapan dan kualifikasi komponen pengelolaan kelembagaan kursus dan pelatihan yang berkaitan dengan status kelembagaan, pengelola, perencanaan, sumber daya manusia, keuangan, sarana dan prasarana, administrasi, pengawasan, dan pelaporan agar tercapai efisiensi dan efektivitas penyelenggaraan pendidikan. Standar pengelolaan mengatur dan memberikan acuan tentang legal standing kelembagaan, jenis dan struktur pengelolaan, pola perencanaan dan struktur organisasi, pedoman pendidikan, pengelolaan sumber daya manusia, pengelolaan keuangan, pengelolaan sarana dan prasarana, pengawasan, dan pelaporan.

Standar pembiayaan adalah standar yang mengatur komponen dan besarnya biaya operasi satuan pendidikan kursus dan pelatihan, yang meliputi sumber pembiayaan, jenis pembiayaan, perencanaan pembiayaan, dan pencatatan keuangan. Standar pembiayaan perlu distandarisasi untuk menjamin akuntabilitas publik.

Standar penilaian pendidikan adalah standar nasional pendidikan yang berkaitan dengan mekanisme, prosedur, dan instrumen penilaian hasil belajar peserta 
didik. Untuk kepentingan standar kursus dan pelatihan standar penilaian meliputi penilaian hasil belajar oleh pendidik, dan penilaian hasil belajar oleh lembaga kursus dan pelatihan, serta penggunaan hasil penilaian.

\section{KESIMPULAN}

Variabilitas jenis dan jenjang kursus menimbulkan kesulitan tersendiri dalam menetapkan standar, khususnya dalam menetapkan batas minimal komponen-komponen yang harus dipenuhi oleh lembaga dan program kursus. Namun demikian bukan berarti standarisasi kursus tidak perlu dan tidak mungkin dilakukan. Standarisasi kursus dapat dilakukan terhadap komponen-komponan generik yang menjadi komponen pokok dalam kelembagaan dan program kursus sesuai dengan nilai dan norma penyelenggaraan pendidikan. Adapun penetapan batas minimal komponen kelembagaan dan program sebaiknya dilakukan secara operasional oleh BAN PNF bersama konsorsium kursus. Dengan demikian batas minimal ini senantiasa dapat disesuaikan dengan karakteristik jenis kursus dan perkembangan kebutuhan lapangan.

Standarisasi sangat dibutuhkan oleh kelembagaan dan program kursus untuk meningkatkan mutu dan menjaga kehormatan lembaga kursus. Standarisasi yang akuntabel dapat meningkatkan kinerja lembaga kursus agar terus meningkatkan mutu, serta menghindarkan adanya lembaga dan program kursus yang tidak bermutu dan tidak bertanggung jawab. Bagi masyarakat, standarisasi kursus dibutuhkan untuk memberikan jaminan akan mutu layanan pembelajaran dan menghindarkan masyarakat dari paktek lembaga dan program kursus yang tidak bertanggung jawab.

\section{DAFTAR PUSTAKA}

Arif, Z. (1986). Andragogi. Bandung: Angkasa.

Coombs, P. (1974). New path to learning for rural children and youth. New Jersey: Prentice Hall, Inc.

Depdiknas, Direktorat Pembinaan Kursus dan Kelembagaan, Ditjen PLS. (2005). Direktori kursus Indonesia 2005. Jakarta: Depdiknas.

Ditjen PLS. (2006). Program prioritas pendidikan luar sekolah dan pemuda tahun 2006. Jakarta: Ditjen PLSP.

Jalal, F. (2004). Kontribusi Pendidikan Luar Sekolah dan Pemuda terhadap Pembangunan Bangsa. Makalah pada Konvensi Nasional Pendidikan Indonesia (KONASPI) V, Surabaya . 6 Oktober 2004.

Rogers, E. M., \& Shomaker, F. (1997). Diffussion of innovation. New York: The Free Press.

Soedomo, M. (1989). Pendidikan luar sekolah ke arah pengembangan sistem belajar masyarakat. Jakarta: Departemen Pendidikan dan Kebudayaan. Direktorat Pendidikan Tinggi
Proyek Pengembangan Lembaga Pendidikan Tenaga Kependidikan.

Soegiyanto, S. (1989). Peranan Pendidikan Luar Sekolah dalam Peningkatan Kualitas Sumberdaya Manusia. Pidato Ilmiah pada Dies Natalis IKIP PGRI Banyuwangi.

Sudjana, H.D. (2000). Pendidikan luar sekolah: Wawasan, sejarah perkembangan, falsafah, teori pendukung, asas. Bandung: Falah Production.

(2002) Undang-Undang Dasar Republik Indonesia Tahun 1945 (Perubahan Pertama, Kedua, Ketiga, dan Keempat)

(2003) Undang-Undang Republik Indonesia Nomor 20 Tahun 2003 tentang Sistem Pendidikan Nasional. Jakarta: Departemen Pendidikan Nasional.

(2005) Peraturan Pemerintah Republik Indonesia Nomor 19 Tahun 2005 tentang Standar Nasional Pendidikan. 